\title{
Residence Rights for Caring Parents who are also Victims of Domestic Violence
}

\author{
Helen Oosterom-Staples \\ Tilburg Law School, the Netherlands \\ arishelen@freeler.nl
}

\begin{abstract}
Traditionally, parents determine their children's right to reside in a host-State. This means that a child's right to remain in a host-State is intrinsically linked to the presence of those parents in their host-State. This changed for the EU Member States with the Court of Justice's ruling in the Baumbast case and was extended in that Court's Chen ruling. In these cases the Court of Justice, as a first step, acknowledged children as independent bearers of residence rights. To ensure the effectiveness of this right to remain, the Court of Justice, as a second step, reasoned that a third-country national parent also enjoys a right to remain in that Member State if that parent is their primary carer. These rulings play a crucial role in the Court of Justice's recent decision in the NA case. Although Article 13(2) of the Citizens Directive provides for a right to remain as a victim of domestic violence, it is not in this capacity but rather her capacity of the primary carer of two young EU-citizens that ensures her a right to remain in her hostMember State after the departure of her EU-citizen spouse.

This contribution seeks an alternative reading of Article 13(2)(c) of the Citizens Directive to that offered by the Court of Justice in the NA case. Arguments are found in that Directive's objectives, drafting history and effectiveness; benchmarks normally used by the Court of Justice in its case law when clarifying the scope of EU free movement rights, as well as that Court's case law on the declaratory nature of those rights.
\end{abstract}

\section{Keywords}

divorce - victim of domestic violence - children - caring parents - derived residence rights - EU-citizenship - third-country national family member 


\section{Introduction}

Traditionally children derive their residence right in a State of which they are not a national, the so-called host-State, from the residence entitlements of their parent(s). European Union (EU) law was no exception. This changed in 2002 when the Court of Justice EU (further: Court of Justice) held that Mr. Baumbast's Columbian wife enjoyed a right to remain in the United Kingdom after he, a German national who had worked in that Member State both as a worker and a self-employed person, moved to China and later Lesotho to pursue an economic activity there. Relying on the principle of effective rights, the Court of Justice argued that if Mrs Baumbast was not entitled to remain in her husband's former host-Member State this would mean that their two children, who were entitled to and actually did attend school in the UK, 'might [be] deprive[d] ... of a right which is granted to them by the [Union] legislator.' ${ }^{1}$ The logic being that the children would have to leave that Member State with their mother, their primary carer, if she could not remain in that Member State and that this, in turn, would impact on the children's right to complete their education in their host-Member State, as provided for in Article 10 of Regulation (EU) No. 492/2011, ${ }^{2}$ and, in its slip stream, their right to remain there for this purpose. It is the Baumbast case law that provides NA, who has been granted sole custody over her two children, with a right to remain in her host-Member State, the UK, after her divorce becomes final in August 2009. To bring NA in her capacity of the primary carer of two young children in education within the scope of the Baumbast case law, so it is held, the Court of Justice has to extend its reading of Article 10 of Regulation (EU) No. 492/2011 to ensure that NA and the children can remain in their hostMember State.

Likewise, in the Chen case the Court of Justice extended a child's right to remain in a host-Member State as an economic inactive EU-citizen ${ }^{3}$ to the third-country national parent who is the primary carer of that child to ensure

1 ECJ Case C-413/99 Baumbast and Rv. Secretary of State for the Home Department, 17 September 2002, ECLI:EU:C:2002:493, cons. 71.

2 Regulation (EU) No. 492/2011 of the European Parliament and of the Council of 5 April 2011 on freedom of movement for workers within the Union (further: Regulation (EU) No. 492/2011), OJ EU 2011, L 141/1.

3 Article $7(1)($ b) of Directive 2004/38/EC of the European Parliament and of the Council of 29 April 2004 on the right of citizens of the Union and their family members to move and reside freely within the territory of the Member States (further: Citizens Directive or Directive 2004/38/EC), OJ EU 2004, L 229/35. 
the effectiveness of the child's residence right. To benefit from the protection offered by this case law, the child must satisfy the residence conditions in Article 7(1)(b) of the Citizens Directive; sufficient resources to prevent that the child and the primary carer need to rely on the social assistance scheme of the host-Member State and a health insurance. Like in the Baumbast case, the Court of Justice's interpretation is premised on the logic that not extending the right to reside in the child's host-Member State to the third-country national primary carer

would deprive the child's right of residence of any useful effect [as i]t is clear that enjoyment by a young child of a right of residence necessarily implies that the child is entitled to be accompanied by the person who is his or her primary carer and accordingly that the carer must be in a position to reside with the child in the host-Member State for the duration of such residence. ${ }^{4}$

As it is the national court that has to assess whether there are sufficient resources and a health insurance, there is no conclusive answer to the question whether NA qualifies as the primary carer of two economic inactive EU-citizens in the Court of Justice's judgment.

In 2011 the Court of Justice introduced the so-called 'genuine enjoyment-test', the third avenue available to third-country national primary carers to derive an EU-right to remain from their children's residence right in a Member State. Using the same logic as in the Baumbast and Chen cases - the effectiveness of a child's right to reside - albeit using different terminology, the Court of Justice reasoned that not granting the primary carer of a child who is an EU-citizen a right to remain in that child's home-Member State amounts to a deprivation of the genuine enjoyment of the substance of the child's right to move and reside ex Article 20(2)(a) of the Treaty on the Functioning of the European Union (TFEU). ${ }^{5}$ This string of case law differs from the first two as it is in the child's Member State of nationality rather than in the child's host-Member State that a right to remain is sought for the third-country national caring parent. As the child, who is a national of the Member State where the third-country national primary carer is seeking permission to remain, automatically enjoys a right to

4 ECJ (Full court) Case C-200/o2 Kunqian Catherine Zhu and Man Lavette Chen v. Secretary of State for the Home Department, 19 October 2004, ECLI:EU:C:2004:639, cons. 45.

5 CJ EU (Grand Chamber) Case C-34/og Gerardo Ruiz Zambrano v Office national de l'emploi (ONEm), 8 March 2011, ECLI:EU:C:2011:124, cons. 42. 
remain there, ${ }^{6}$ the Court of Justice does not have to consider whether and if so what the legal basis is of the child's residence entitlements in that Member State. The Court of Justice dismisses the option that NA qualifies for a right to remain under the Ruiz Zambrano case law. As MA and IA are German nationals who are resident in the UK, they are making use of their freedom of movement right and, therefore, the Ruiz Zambrano-case law does not apply to their situation. ${ }^{7}$ The reason offered by the Court of Justice to dismiss this case law is, however, that it only covers situations in which 'the person concerned does not qualify for a right of residence in that Member State under European Union secondary law'. In the $N A$ case the children derive a right to remain in the UK from Article [10 of Regulation (EU) No 492/2011]. ${ }^{8}$

Although it is welcomed that the Court of Justice recognises children as rights bearers and givers, it is sad that that Court does nothing for NA in her capacity of a victim of domestic violence for whom the EU-legislator has provided a personal right to remain in Article 13(2)(c) of the Citizens Directive. Recognising NA as the primary carer of two children who are EU-citizens under the terms of the Baumbast or the Chen case law means that her right to remain is not a personal one, as it would have been under Article 13(2)(c)of the Citizens Directive, but one that she derives from and is linked to the presence of her children in her host-Member State and their need for her care; it serves the purpose of upholding the effectiveness of her children's right to reside in their host-Member State. It is felt that a focus on adults as the primary carer of children might provide a (temporary) solution for some, but for others, i.e. those who do not have children or whose children have accompanied their EUcitizen parent when s/he left the host-Member State, either voluntarily or by force, this is not the case. Furthermore, by subjecting the right to remain as a victim of domestic violence to the condition that divorce was applied for prior to the EU-citizens departure from the Member State where the couple lived

6 Article 3(2) Protocol No. 4 to the Convention for the Protection of Human Rights and Fundamental Freedoms, securing certain rights and freedoms other than those already included in the Convention and in the first Protocol thereto, 16 September 1963, ETS No. 46.

7 E.g. CJ EU (Grand Chamber) Case C-256/11 Murat Dereci a.O.v Bundesministerium für Inneres, 15 November 2011, ECLI:EU:C:2011:734 cons. 64 \& 66-67; (Third Chamber) C-40/11 Yoshikazu Iida v Stadt Ulm, 8 November 2012, ECLU:EU:C:2012:691, cons. 71; (Second Chamber) Case C-87/12, Kreshnik Ymeraga a.O. v Ministre du Travail, de l'Emploi et de l'Immigration, 8 May 2013, ECLI:EU:C:2013:291, cons 36; and (Second Chamber) Case C-86/12, Adzo Domenyo Alokpa a.O.v Ministre du Travail, de l'Emploi et de l'Immigration, 10 October 2013, ECLI:EU:C:2013:645, cons. 32 .

8 CJ EU (First Chamber) Case C-115/15 Secretary of State for the Home Department v NA, 30 June 2016, ECLI:EU:C:2016:487, cons. 73-74. 
during their marriage, as the Court of Justice does (infra, § 2.3), leaves the victim of domestic violence with 'no protection against blackmail, or other abuse, between the time on which any domestic violence first occurs, and eventual divorce. ${ }^{9}$

This contribution seeks to answer the question whether an alternative interpretation-i.e. a different one than the one given by the Court of Justice in the NA case- of Article 13(2)(c) of the Citizens Directive is possible; one that preserves the effectiveness of the right to remain as a victim of domestic violence. Section 2 will focus on the Court of Justice's reading of Article 13(2) (c) of the Citizens Directive in the NA case. This case will be introduced in $\S 2.1$ and the Court of Justice's reasoning regarding the right to remain as a victim of domestic violence will be presented in $\S 2.2$ and $\S 2.3$. This discussion will be followed by a critical reflection on the Court of Justice's reasoning in the $N \mathrm{~A}$ case by considering it in the light of its own case law that puts the effectiveness of free movement rights accorded to EU-citizens centre stage in $\S 2.4$. Are there arguments which have been used by the Court of Justice in the past that it could have used in the $N A$ case to justify a reading of the right to remain as a victim of domestic violence that does not depend on the presence of the EU-citizen in the host-Member State at the time when divorce proceedings are filed? Section 2 will be followed by a discussion of the Court of Justice's case law on the right to remain as a primary carer of children in education in section 3. The introduction of the case law in $\S 3.2$ will be followed by an assessment of the Court of Justice's findings in $N A$ in $\S 3.3$, that will question whether the Court of Justice's extensive reading of the right to remain as a primary carer in the NA case should be favoured over a reading of Article 13(2) (c) of the Citizens Directive that excludes victims of domestic violence who fail to apply for divorce before the EU-citizen leaves the host-Member State from its scope. Section 4 will move beyond the Court of Justice's case law, questioning whether a victim oriented reading of Article 13(2)(c) of the Citizens Directive could be achieved considering the envisaged accession of the EU to the Council of Europe's Convention on Preventing and Combating Violence against Women and Domestic Violence. ${ }^{10}$

Written Observations on behalf of the AIRE Centre in the preliminary reference by the Court of Appeal of England and Wales in the Appeal between Nazia Ahmed ('NA' (Pakistan') — appellant — and Secretary of State for the Home Department-Respondent, Case C-115/15, $\S 16$ and the Annex to these Observations with examples of request for advice on the right to remain following a breakdown of a relationship with an EU-citizen (further: Written Observations Aire Centre), p. 5, point No. 16 (on file with the author). 


\section{A Restrictive Reading of a Victim of Domestic Violence's Right to Remain in the Citizens Directive}

\subsection{Introducing the NA Case; Facts and Legal Framework}

The key question which the Court of Justice has to answer in the NA case is whether NA, who was a victim of domestic violence during her marriage, derives a right to remain in the UK from Article 13(2)(c) of the Citizens Directive following her divorce, as her former husband left her host-Member State before divorce proceedings had been started.

NA is a Pakistan national who married a German national (KA) in September 2003. She moved to the UK in March 2004 where she lived together with her husband until he left the matrimonial home in October 2006. During NA's marriage to $\mathrm{KA}$, she is a victim of domestic violence on a number of occasions. Whilst in the UK, KA worked as both a worker and a self-employed person. The couple is divorced according to Pakistani law (talaq) on 13 March 2007 and according to British law on 4 Augustus 2009. Whereas KA purported the divorce by a talaq, it is NA who, in September 2008, seeks divorce according to UK law. The divorce settlement under UK law specifies that NA holds sole custody of the two children. The couple's first child (MA) was born on 14 November 2005. She has attended school in the UK since January 2009. February 2007 saw the birth of the second child (IA). IA starts school in September 2010. Whereas the couple live to together as spouses in the UK when MA is born, IA was born approximately four months after her father has left her mother and two months after he has left the UK. Both children are German nationals and start their school careers after their father's departure from the UK.11

When her divorce is final, NA applies for a right to remain in the $\mathrm{UK}$, invoking Article 13(2)(c) of the Citizens Directive. This provision reads:

Without prejudice to the second subparagraph, divorce, annulment of marriage or termination of the registered partnership referred to in point 2(b) of Article 2 shall not entail loss of the right of residence of a Union citizen's family members who are not nationals of a Member State where (..) this is warranted by particularly difficult circumstances, such as having been a victim of domestic violence while the marriage or registered partnership was subsisting. ${ }^{12}$

\footnotetext{
$11 N A$, nt. 8, cons. $15^{-20 .}$

12 In this contribution where marriage is used in relation to Article $13(2)$ (c) of the Citizens Directive it should be read as also including registered partnerships.
} 
The application for a right to remain under the terms of Article 13(2)(c) of the Citizens Directive is made even though NA can remain in the UK under that Member State's domestic law; the lower court has already established that to require NA to leave the UK and move either to Germany (the children's country of nationality) or Pakistan (NA's country of nationality) would amount to a breach of either Article 7 of the Eu's Charter on Fundamental Rights ${ }^{13}$ or Article 8 ECHR. ${ }^{14}$ NA's application for protection by EU law is explained by the fact that she will enjoy a higher level of protection under Eu law than what is offered to her by domestic migration law..$^{15}$

At the time of the ruling, the Court of Justice had only handed down one other case in which it had been requested to interpret Article 13(2) of the Citizens Directive, the Kuldip Singh case. ${ }^{16}$ Its findings in this case are used and developed by the Court of Justice in the NA case. It is therefore the Kuldip Singh case that needs to be considered first.

\subsection{The Kuldip Singh-Ruling}

2.2.1 Introducing the Facts and Legal Framework

The Kuldip Singh case concerned the right to remain in Ireland of four former third-country national spouses of EU-citizens who wished to remain in Ireland where they lived with their EU-citizen spouse when married and have not applied for divorce before their former EU-citizen spouse leaves that Member State. Unlike NA, the third-country nationals in Kuldip Singh were not a victim of domestic violence. Therefore, they did not rely on Article 13(2)(c) of the Citizens Directive as the legal basis for their right to remain, but Article 13(2) (a) of that directive. This provision sets out the terms for a personal right of residence following divorce or termination of a registered partnership if

prior to initiation of the divorce or annulment proceedings or termination of the registered partnership (...), the marriage or registered partnership has lasted at least three years, including one year in the host-Member State.

13 Charter of Fundamental Rights of the European Union, oJ EC 2007, C 303/1.

14 Court of Appeal (Civil Division) Decision, the Secretary of State for the Home Department (Appellant) and NA (Pakistan) (Respondent), February 25, 2015, Case No: C5/2013/1871 \& C5/2013/1977 [2015] EWCA Civ 140, § 11 (available at: http://www.bailii.org/ew/cases/ EWCA/Civ/2015/140.html).

15 Written Observations Aire Centre, nt. 9, p. 2, point No. 3.

16 CJ EU (Grand Chamber) Case C-218/14 Kuldip Singh and Others $v$ Minister for Justice and Equality, 16 July 2015, ECLI:EU:C:2015:476. 
The Court of Justice's interpretation of Article 13(2)(a) of the Citizens Directive in the Kuldip Singh case is premised on the limited personal scope of that Directive. First of all, third-country nationals have to qualify as a family member of an EU-citizen within the meaning of Article 2(2) of the Citizens Directive to enjoy a right to remain there under this directive. Secondly, the third-country national family member has to move to the host-Member State with the EUcitizen or join him/her there. ${ }^{17} \mathrm{~A}$ third-country national's rights are, therefore, derived by nature rather than independent or autonomous rights and depend on the joint presence of the EU-citizen and the third-country national family member in the host-Member State. ${ }^{18}$ The protection offered to a third-country national is thus designed to preserve the effectiveness of an EU-citizen's free movement rights as set out in the Citizens Directive. ${ }^{19}$ Effectiveness, as it is used here by the Court of Justice, means that

a refusal to allow such rights [read: derived rights for third-country national family members] would be liable to interfere with the Union citizen's freedom of movement by discouraging him from exercising his rights of entry into and residence in the host-Member State. ${ }^{20}$

The notion of effectiveness as it is used here by the Court of Justice to justify that both the third-country national family member and the EU-citizen have to be present in the host-Member State to trigger the operation of the Citizens Directive vis-à-vis the third-country national in that Member State, does not extend as far as to require the spouses to cohabit in that Member State; they merely have to live there at the same time. ${ }^{21}$ So, according to the case law third-country nationals only benefit from the protection offered by the Citizens Directive if they

\footnotetext{
17 Article 3(1) Directive 2004/38/EC.

18 CJ EU (Grand Chamber) Case C-456/12 O v Minister voor Immigratie, Integratie en Asiel and Minister voor Immigratie, Integratie en Asiel v B, 12 March 2014, ECLI:EU:C:2014:135, cons. $39 \& 63$.

19 CJ EU Cases C-370/9o The Queen v Immigration Appeal Tribunal and Surinder Singh, ex parte Secretary of State for Home Department, 7 July 1992, ECLI:EU:C:1992:296, cons. 25 \& 35; (Grand Chamber) C-291/05 Minister voor Vreemdelingenzaken en Integratie $v$ RNG Eind, 11 December 2007, ECLI:Eu:C:2007:771, cons. 35, 36 \& 45, Iida, nt. 7, cons. 70 and $O \&$ $B$, nt. 18 , cons. 46 .

$20 \quad$ Kuldip Singh, nt. 16, cons 50. See also: $O \& B$, nt. 18, cons. $36 \& 45$.

21 CJ EU (Second Chamber) Case C-244/13, Ewaen Fred Ogieriakhi v Minister for Justice and Equality and Others, 10 July 2014, ECLI:EU U:C:2014:2068, cons. 39, Iida, nt.7, cons. 63-64 and Kuldip Singh, nt. 16, cons. 54-55.
} 
(i) are a family member within the meaning of Article 2(2) of the Citizens Directive; and

(ii) 'accompany' or 'join' an EU-citizen to/in the latter's host-Member State.

The EU-citizen must, in turn, satisfy the conditions for residence in Article $7(1)(a),(b)$ or (c) of the Citizens Directive, i.e. qualify as an economic active or an economic inactive person or a student. ${ }^{22}$

The legal basis for the third-country national's right to remain is Article $7(2)$ of the Citizens Directive that reads: 'The right of residence provided for in paragraph 1 shall extend to family members who are not nationals of a Member State, accompanying or joining the Union citizen in the host-Member State, provided that such Union citizen satisfies the conditions referred to in paragraph l(a), (b) or (c).' Although there is no obligation to actually live together in the host-Member State to qualify for protection as the spouse of an EU-citizen under the Citizens Directive, the departure of the latter from the host-Member State means that the status of a family member who has accompanied or joined the EU-citizen to/in the host-Member State is lost, as the residence conditions, as set out in Article 7(2) of Directive 2004/38/EC, are no longer satisfied..$^{23}$ This follows from Article 14(2) of that Directive that reads 'Union citizens and their family members shall have the right of residence provided for in Articles 7, 12 and 13 as long as they meet the conditions set out therein.' It is at this moment that Articles 12 and 13 of the Citizens Directive kick in as options to solve the residence gap. The first provision sees to situations in which the EU-citizen has past away or departs from the host-Member State. The latter is designed to provide protection in cases where the marital or partner relationship is officially terminated. It is the reading to be given to this provision that the Court of Justice is concerned with in both the Kuldip Singh and NA cases.

\subsubsection{Filing for Divorce Prior to the EU-Citizen's Departure from the} Host-Member State

The two phrases in Article 13(2)(a) of the Citizens Directive which are crucial in the Court of Justice's reading of that provision in the Kuldip Singh case are: 'the host-Member State' and 'initiation of divorce ... proceedings' which, read together, restrict the protection offered by that provision to cases where

the spouse who is a Union citizen of a third-country national (...) reside[s] in the host-Member State, in accordance with Article 7(1) of Directive

22 Kuldip Singh, nt. 16, cons. 50-56.

23 Ibidem, cons. 57-58. 
2004/38/EC, up to the date of commencement of the divorce proceedings for that third-country national is to be able to claim the retention of his or her right of residence in that Member State, on the basis of Article $13(2)$ of the directive. ${ }^{24}$

The Court of Justice's reading of Article 7(2) of the Citizens Directive is that it merely provides for the retention of an existing residence right. The EUcitizen's departure from the host-Member State means that the third-country national family member loses the right to remain under the Citizens Directive and, as a consequence, no longer enjoys an existing right under that Directive. ${ }^{25}$ This loss of the right to reside ex Article 7(2) of the Citizens Directive cannot be remedied through the operation of Article 13(2)(a) of the Citizens Directive. This, so the Court of Justice reasons, would exactly be achieved if the protection offered by this provision was extended to third-country nationals who fail to apply for divorce before the EU-citizen spouse leaves the host-Member State.

Though there are good reasons to question the Court of Justice's interpretation of Article 13(2)(a) of the Citizens Directive (infra, § 2.4), for now, the analysis will focus on the reasons given by that Court in the $N A$ case to justify that, likewise, the victim of domestic violence only benefits from the protection offered by sub-section (c) of that provision if the EU-citizen is present in the host-Member State at the time when the application for divorce is filed. ${ }^{26}$

\subsection{NA: Developing the Kuldip Singh Rule}

Relying on its findings in the Kuldip Singh case, the Court of Justice subjects the right to remain as a victim of domestic violence in Article 13(2)(c) of the Citizens Directive to the condition that an application for divorce has been made prior to the EU-citizen's departure from the host-Member State. For NA this means that as she has not filed for divorce before her spouse's departure from the UK, she does not qualify as a beneficiary of Article 13(2)(c) of the Citizens Directive. ${ }^{27}$ The Court of Justice reaches this conclusion using a literal, contextual and teleological analysis of a victim of domestic violence's right to remain.

Both the literal and contextual analysis of Article 13(2) of the Citizens Directive provided by the Court of Justice in the $N A$ case draw heavily from its findings in the Kuldip Singh case, i.e.

\footnotetext{
24 Ibidem, cons. 66.

25 Ibidem, cons. 67.

$26 \quad N A$, nt 8, cons. 35-36.

27 Ibidem, cons. 17, 20 \& 49 .
} 
(i) A third-country national family member only benefits from the protection offered by the Citizens Directive in an EU-citizen's host-Member State when and for as long as he/she resides there with that EU-citizen; and

(ii) Article 13(2) of the Citizens Directive only provides a right to remain if divorce proceedings are lodged prior to the departure of the EU-citizen spouse from the host-Member State as it is designed to provide protection if the third-country national enjoys an existing right to remain in that Member State.

After reiterating this case law, the Court of Justice concludes that Article 13(2) (c) of the Citizens Directive must be 'interpreted in the light of the whole first sub-paragraph of Article 13(2).28 For the literal reading of the right to remain in sub-section (c) this means that both the heading and text of that provision dictate that to obtain a right to remain a third-country national must satisfy the conditions laid down in that provision. If this is the case, then 'divorce does not entail loss of such a right of residence.'. ${ }^{29}$

The contextual analysis moves beyond the Court of Justice's findings in the Kuldip Singh case. After reiterating the implications of the derived nature of a third-country national family member's right to reside under the Citizens Directive, the Court of Justice reads Article 13(2) in combination with Article 12 of that Directive. The latter provision sets out when family members can remain in the host-Member State on the occasion of an EU-citizen's death or departure from that Member State. This provision distinguishes between family members who are EU-citizens themselves and those who are third-country nationals. The former are accorded a right to remain if they satisfy the conditions in Article 12 of the Citizens Directive both in the event of the death and the departure of the EU-citizen sponsor. This is not, however, the case for thirdcountry national family members. According to the terms of Article 12 of the Citizens Directive the latter can only remain in the host-Member State in the event of the EU-citizen's death. The explicit choice made by the EU-legislator, namely not to protect third-country national family members when the EUcitizen leaves the host-Member State, so the Court of Justice reasons, cannot but impact on the interpretation of Article 13(2) of Directive 2004/38/EC. In the words of the Court of Justice:

28 Ibidem, cons. 38 .

29 Ibidem, cons. 40. 
it is therefore clear that, when that directive was adopted, the EU legislature declined to make provision, in the event of the departure from the host-Member State of the Union citizen, for specific safeguards that would be available, on account of, inter alia, particularly difficult situations, to his family members who do not have the nationality of a Member State, that would be comparable to those provided for in Article 13(2)(c) of Directive 2004/38/Ec. ${ }^{30}$

What the Court of Justice remains silent on, is that Article 12(3) of the Citizens Directive provides for the retention of the right to remain if the EU-citizen parent leaves the host-Member State and on the occasion of his/her death, both for the children and the parent who has custody of the children, irrespective of their nationality, if the children are resident in the host-Member State and 'are enrolled at an education establishment, for the purpose of studying there until the completion of their studies'.

The Court of Justice completes its reasoning in consideration 45 where it spells out the objective of Article 13(2) of the Citizens Directive, reading this provision in combination with recital 15 of the Citizens Directive. This recital reads:

Family members should be legally safeguarded in the event of the death of the Union citizen, divorce, annulment of marriage or termination of a registered partnership. With due regard for family life and human dignity, and in certain conditions to guard against abuse, measures should therefore be taken to ensure that in such circumstances family members already residing within the territory of the host Member State retain their right of residence exclusively on a personal basis.

The combined effect of recital 15 and Article 13(2) of the Citizens Directive is to provide legal safeguards to family members in the event of the death and on the breakup of a relationship if they are 'already residing within the territory of the host-Member State [allowing them to] retain their right of residence exclusively on a personal basis' if the family members themselves satisfy the conditions in Article 7(1)(a), (b) or (c) of the Citizens Directive.

Moving from the objective of Article 13(2) of the Citizens Directive to its drafting history the Court of Justice continues its reasoning in consideration 46 as follows. Drawing from the European Commission's explanatory memorandum it points out that under the predecessors of the Citizens Directive 'the

Ibidem, cons. 44 . 
divorced spouse could be deprived of the right of residence in the host-Member State'. It is this gap in the protection of a spouse that Article 13(2) of the Citizens Directive aims to fill by providing

certain legal safeguards to third-country nationals whose right of residence was dependent on a family relationship by marriage and who could therefore be open to blackmail accompanied by threats of divorce, and that safeguards were necessary only in the event of final divorce, since, in the event of de facto separation, the right of residence of a spouse who is a third-country national is not at all affected. ${ }^{31}$

Notwithstanding this acknowledgement that the very purpose why thirdcountry national family members are protected on the occasion of a breakdown of their relationship, the Court of Justice's states in consideration 48 that

an interpretation of Article 13(2)(c) of Directive 2004/38/EC to the effect that a third-country national is entitled to rely on the right derived from that provision where her spouse, who is a Union citizen, has resided in the host Member State, in accordance with Article 7(1) of Directive 2004/38, not until the date of the commencement of divorce proceedings but, at the latest, until the date when the domestic violence occurred, is contrary to the literal, systematic and teleological interpretation of Article 13(2) of Directive 2004/38/EC.

As Article 13(2)(c) of the Citizens Directive 'is dependent on the parties concerned being divorced', this means that the EU-citizen has to be resident in the host-Member State, 'in accordance with Article 7(1) of Directive 2004/38/ $\mathrm{EC}$, until the date of the commencement of divorce proceedings, if that thirdcountry national is to be entitled to rely on Article 13(2)(c) of that directive., ${ }^{32}$

\subsection{An Appraisal}

Although the Court of Justice does consider the drafting history of Article 13(2)(c) of the Citizens Directive where it establishes that its purpose is 'to offer certain legal safeguards to third-country nationals whose right of residence was dependent on a family relationship by marriage and who could therefore be open to blackmail accompanied by threats of divorce,',33 the consequence of

31 Ibidem, cons. 47.

32 Ibidem, cons. $5^{0 .}$

33 Ibidem, cons. 47. 
the Court of Justice's reading given to this provision is, however, precisely the opposite. The restrictive reading offered by the Court of Justice, so it is argued, serves the perpetrator rather than the victim, as a threat to leave the hostMember State is easily made by the perpetrator to keep the victim of domestic violence in check if there is any mentioning of reporting the incident(s) to the police or any other person or authority. The question is whether this restrictive reading is the only one that is legally sound.

\subsubsection{Challenging the Literal Reading}

Let us start with the first paragraph of Article 13(2) of the Citizens Directive. According to the Court of Justice's reading of this provision in both the Kuldip Singh and the NA case, the wording used in the heading of this section restricts its application to situations in which the EU-citizen is located in the hostMember State when divorce proceedings are initiated. Reiterating, the conclusion that the Court of Justice draws, is that the use of the word 'retention' in the heading of Article 13 of the Citizens Directive means that the purpose of this provision is to ensure that an existing right of residence is not lost. To retain, as it is used here, therefore means: 'to preserve' or 'something you continue to keep. ${ }^{34}$

But what is preserved by using the word 'retention' in the heading of Article 13 of the Citizens Directive. To answer this question we must relate the word 'retention' to the wording used in the first paragraph of Article 13(2) of the Citizens Directives, namely 'divorce ... shall not entail loss of the right of residence of a Union citizen's family members ... Read in this context the conclusion could just as easily have been the opposite; namely that through the operation of Article 13(2) of the Citizens Directive the right that family members derive from Article $7(2)$ of that Directive in the first place is not lost at all the moment that any one of the four situations listed in sub-sections a-d of Article 13(2) of the Citizens Directive occurs. This reading is not only justified by the choice of wording used in the English text of this provision, but is also justified by the choice of words used in the Dutch ('... leiden scheiding, ontbinding of nietigverklaring van het huwelijk ... niet tot verlies van het verblijfsrecht van de familieleden....'), French ('le divorce, l'annulation du marriage ... n'entraîne pas la perte du droit de séjour des membres de la famille d'un citoyen de l'Union'), and German ('... führt die Scheidung oder Aufhebung der Ehe ... für Familienangehörige eines Unionsbürgers ... nicht zum Verlust des Aufenthaltsrechts') text of this section. A literal reading of this provision could, therefore, also justify the conclusion that reliance on Article 13(2) of the Citizens 
Directive is possible if and when one of the four situations listed in sub a-d occurs.

The operation of the law would mean that the residence right derived from Article $7(2)$ of the Citizens Directive whilst in a relationship with an EU-citizen with whom the (third-country national) family member resided in the hostMember State is automatically transformed into an exclusive, personal right of residence when one of the four situations in Article 13(2)(a)-(d) of the Citizens Directive occur, subject to the condition that the third-country national must satisfy the additional requirement that he/she qualifies for a right to remain under Article 7(1)(a), (b), (c) or (d) of the Citizens Directive. This reading improves the position of a spouse who is also a caring parent beyond the protection offered by the Baumbast case law, in the sense that the right to remain accorded to the caring parent in that case law is a derived rather than a personal right (infra, § 3).

From the facts given in the Court of Justice's judgment it is not possible to establish whether NA would qualify for a right to remain under Article 7(1)(a), (b) or (d) of the Citizens Directive. To qualify under sub-section (a), she will have to pursue an economic activity. To qualify under sub-section (b) she would have to provide evidence of sufficient financial means and a health insurance. To qualify under (d) her children would have to qualify as economic inactive EU-citizens by virtue of the fact that a third party, which could be their mother, father or any other third party, provides them with sufficient resources.

\subsubsection{Analogous Application of the Kuldip Singh Ruling}

My second comment concerns the seemingly ease with which the Court of Justice applies its reading of Article 13(2)(a) of the Citizens Directive in the Kuldip Singh case by analogy to the right to remain accorded to victims of domestic violence, notwithstanding the difference in wording used in the two sub-sections. Where sub-section (a) provides that the right of residence is not lost where 'prior to initiation of the divorce ... the marriage ... has lasted three years, including one year in the host-Member State (emphasis added)', sub-section (c), merely refers to situations which should not entail the loss of a residence right if 'this is warranted by particularly difficult circumstances, such as having been a victim of domestic violence while the marriage ... was subsisting'.

The crucial difference between the two sub-sections is that the word 'divorce' is not used in sub-section (c). As the moment that the divorce proceeding is initiated, is crucial in the Court of Justice's reading of this sub-section, in my opinion, this difference in wording should not have been overlooked by that court. Even if we acknowledge that a literal reading of Article 13(2)(a) of 
the Citizens Directive merits the conclusion that the EU-citizen's departure from the host-Member State entails the loss of the right of residence derived from Article 7(2) of the Citizens Directive that cannot be repaired by Article 13(2)(a) of that Directive, the omission of any reference to the initiation of divorce proceedings in sub-section (c) challenges the Court of Justice's conclusion that the same holds true for victims of domestic violence. At the very least, the Court of Justice should have noted this difference in wording and, preferably, explained why, notwithstanding the omission of a reference to divorce proceedings in Article 13(2)(c) of the Citizens Directive the moment that divorce proceedings are lodged should determine whether or not a thirdcountry national can invoke that provision successfully.

\subsubsection{Protecting the Perpetrator or the Victim, that is the Question?}

My third point concerns the reading given to Article 13(2)(c) of the Citizens Directive by the Court of Justice where it relies on the drafting history. Reiterating, the drafting history reveals that the very purpose of Article 13(2) (c) of the Citizens Directive is to protect victims of domestic violence against threats of divorce ${ }^{35}$ or violence which they continue to endure for fear of losing their right of residence ${ }^{36}$ by their EU-citizen spouse, the perpetrator of domestic violence. However, the very reading given by the Court of Justice in the $N A$ case of this provision actually achieves the opposite. By subjecting the protection offered to victims of domestic violence to the condition that divorce proceedings are lodged before the EU-citizen spouse leaves the host-Member State, the Court of Justice's reading of that provision actually hands the perpetrator power over the victim on the proverbial 'silver plate'. It does not require much imagination to visualise a situation in which the perpetrator of domestic violence threatens to leave the host-Member State, maybe even taking the children with him/her, and spelling out the immediate consequences for the third-country national victim's right to remain if the latter reports any incident

35 Amended Proposal for a Directive of the European Parliament and of the Council on the Right of Citizens of the Union and their Family Members to Move and Reside Freely within the Territory of the Member States, Brussels 15 April 2003, 2001/o111 (COD), СOM(2003) 199 final, p. 7. See also: Written Observations AIRE Centre, nt. 9, pp. 5 \& 7 .

36 Proposal for a European Parliament and Council Directive on the Right of Citizens of the Union and their Family Members to Move and Reside Freely within the Territory of the Member States, Brussels 23 May 2001, 2001/o111 (COD), COM(2001) 257 final, p. 15. See also: Written Observations AIre Centre, nt. 9, pp. 5 and 7. 
of violence to the police or even mentions the occurrence of domestic violence to a third party. ${ }^{37}$

Bearing this in mind, I find it difficult to comprehend why the Court of Justice feels that 'safeguards were necessary only in the event of final divorce, since, in the event of de facto separation, the right of residence of a spouse who is a third-country national is not at all affected. ${ }^{38}$ This might hold true for some divorces, as was the case in the 1985 Diatta case where the Court of Justice established that only a de iure separation requires reconsideration of a family member's right of residence because EU-law does not list cohabitation with the EU-citizen as a condition to enjoy a right of residence as a family member in the EU-citizen's host-Member State; qualifying as a family member within the meaning of Article 2(2) of the Citizens Directive suffices. ${ }^{39}$ The sad lesson of the Kuldip Singh and NA cases is precisely that a de facto separation might affect the right of residence of the third-country national spouse, namely if the EU-citizen leaves the host-Member State before divorce proceedings have been instigated. In my opinion, therefore, a reading of Article 13(2) of the Citizens Directive requiring that the application for divorce is made before the EU-citizen leaves the host-Member State sits uneasily with the notion of effective rights.

\subsubsection{The Declaratory Nature of Residence Rights}

My fourth point is that a reading of Article 13(2) of the Citizens Directive that ensures protection for the victim of domestic violence is also justified by the case law of the Court of Justice on the declaratory nature of the right to free movement accorded to EU-citizens and their family members. This point is closely related to and develops the point made in $\S$ 2.4.1.

According to the Court of Justice's case law, EU-citizens and their family members derive their right of residence in their host-Member State directly from EU (secondary) law when they satisfy the conditions subject to which they can remain there. The logic underlying this case law is that any decision taken by the authorities of the host-Member State regarding the entry and residence entitlements confirms an existing right rather than establishing it, precisely because those rights are conferred directly on EU-citizens and their

Written Observations AIRE Centre, nt. 9, p. 7 and the Annex with examples of requests for advice on the right to remain following a breakdown of a relationship with an EU-citizen, received by the Aire Centre since 2008 (on file with the author).

$38 \quad N A$, nt. 8 , cons. 47 .

39 ECJ Case 267/83 Aissatou Diatta v Land Berlin, 13 February 1985, ECLI:E U:C:1985:67, cons. 18-22. 
family members by EU (secondary) law. A residence permit issued to a beneficiary of free movement rights therefore serves the purpose of proving 'the individual position of a national of another Member State with regard to provisions of European Union law'.40 As a corollary, the fact that an EU-citizen has been issued a residence permit that is still valid does not mean that residence in a Member State is lawful. This is only the case if and for as long as an EUcitizen or a family member satisfies the conditions for lawful residence as provided for by EU (secondary) law. ${ }^{41}$

If, as a general rule, there is a right of residence the very moment that beneficiaries of free movement rights satisfy the conditions subject to which there is a right of residence, then this would mean that third-country national family members enjoy a right to remain, as provided for by Article 13(2) of the Citizens Directive, the moment that the conditions, subject to which a right to remain is accorded to them in that provision, are satisfied. For victims of domestic violence this means that the only factor that determines whether they can rely on Article 13(2)(c) of the Citizens Directive is the occurrence of domestic violence when they are married to an EU-citizen. Unlike the right to remain in sub-section (a) of this provision there is no reference to time slots which need to be completed in this sub-section. Therefore it is not relevant how long they have been married to or resident in the host-Member State as a family member of an EU-citizen at the time they fall victim to domestic violence.

Admittedly, this reading will require defining what domestic violence is, but this is a task that also needs to be accomplished, however difficult this might be, if the whereabouts of the EU-citizen at the moment that divorce proceedings were commenced determines the right to remain as a victim of domestic violence. Likewise which evidence is needed to substantiate a claim of domestic violence will also have to be established, i.e. reports to the police or any other authority, medical testimonies regarding injuries sustained or statements of third parties. Evidence, however, should also not be a primary concern when determining the actual scope of protection offered by the Citizens Directive to victims of domestic violence in the first place.

40 See, for instance: ECJ (Grand chamber) Case C-408/03, Commission v Belgium, 23 March 2006, ECLI:EU:C:2006:192, cons. 62-63 \& 65 \& CJ EU (Third chamber) Case C-325/o9, Secretary of State for Work and Pensions v Maria Dias, 21 July 2011, ECLI:Eu:C:2011:498, cons. 48-49.

Dias, nt. 39, cons. 54 . 
As far as the right to remain in Article 13(2)(a) of the Citizens Directive is concerned, applying the doctrine of the declaratory nature of residence rights to this sub-section means that whenever a marriage breaks up that has lasted for at least three years before proceedings to end the marriage were initiated, a third-country national spouse can remain in the host-Member State if s/ he has lived in that Member State for one year as a family member of an EUcitizen when those proceedings are initiated. The issue of evidence appears less complicated for this sub-section as a document (dated at least three years ago) attesting the marriage should suffice as evidence of the date of marriage. The date of registration as the family member within the meaning of Article 2(2)(a) of the Citizens Directive with the authorities in the host-Member State should suffice as evidence of one year residence in that Member State. To register as a family member of an EU-citizen, a document attesting the relationship is required, so this would not impose an extra burden on the third-country national seeking residence permission. ${ }^{42}$ Admittedly, a complicating factor is that marriages convened outside the $\mathrm{EU}$ are not necessarily corroborated by a written document and there is the issue of the authenticity of documents submitted as evidence that residence conditions are satisfied. This, however, is the case for all applications for residence as a family member of an EU-citizen and, therefore, should be resolved in general and not be turned into a reason to reject a broader interpretation of Article 13(2)(a) of the Citizens Directive than the Court of Justice has given to this provision in the Kuldip Singh case.

\subsubsection{Limiting the Scope of the Proposed Reading}

On a final note it is acknowledged that the observant reader can justly argue that the broad reading of Article 13(2)(c) of the Citizens Directive proposed in this section could mean that a third-country national can claim a right to re-enter and remain in a Member State where s/he has resided at some time in the past whilst in a relationship with an EU-citizen that was formally ended after the couple left that Member State. Such claims are counteracted by the very wording of recital 15 of the Citizens Directive. The words 'already residing within the territory of the host-Member State' that are used in this recital imply that protection only has to be offered to third-country national family members who are resident in the host-Member State at the time when the marriage comes to an end.

42 Articles 8(5)(b) and 10(2)(b) Directive 2004/38/EC. 


\section{Derived Residence Rights for Caring Parents: Revisiting the} Case Law

\subsection{Introduction}

The analysis of the NA case in section 2 reveals that though NA is a victim of domestic violence when married to a German citizen and resident in the UK, she cannot rely on Article 13(2)(c) of the Citizens Directive to safeguard her right to remain in her host-Member State, because her spouse left the U $\mathrm{k}$ before they had applied for divorce. The Court of Justice does not, however, leave her empty-handed. In considerations 66-68 it establishes that NA qualifies for a right of residence in the $\mathrm{UK}$ as she has been granted sole custody of her children and is therefore to be treated as the primary carer of the two children and in that capacity qualifies for a derived right to remain under Article 10 of Regulation (EU) No 492/2011, notwithstanding the fact that the children did not attend school in their host-Member State at the time when their EU-citizen father left that Member State. This reading of Article 10 of Regulation (EU) No. 492/2011 moves beyond the existing case law. This case law is analysed in $\S 3.2$ and challenged in $\S 3 \cdot 3$.

The Court of Justice also considers that NA might qualify for a right to remain in her host-Member State as the primary carer of two EU-citizens who are entitled to reside in that Member State as economic inactive EU-citizen under Article 7(1)(b) of the Citizens Directive, subject to the assessment by the national court that the conditions in that provision are satisfied. ${ }^{43}$ The Court of Justice rejects the possibility of a right to remain under the terms of the Ruiz Zambrano case law, as this case law only kicks in where there is no right to remain under EU secondary law at all. As it has already been established that NA can remain in the UK as she is the primary carer of two children in education within the meaning of Article 10 of Regulation (EU) No. 492/2011, it dismisses this option. ${ }^{44}$

\subsection{Ensuring the Effectiveness of a Child's Right to Education 3.2.1 Introducing the Baumbast and R Families}

As said in the introduction, the first time that the Court of Justice recognised children as bearers of personal residence rights was in the Baumbast \& $R$ case. This ruling concerns two families. The first is the Baumbast family that consists of a German father, a Columbian mother and two children. The eldest, Maria, is the daughter of Mrs Baumbast and holds the Columbian nationality.

\footnotetext{
$43 \quad N A$, nt. 8, cons. 79 .
}

44 Ibidem, cons. 73-74. 
The youngest, Idanella, is the daughter of both Mr \& Mrs Baumbast and is both a Columbian and a German national. Like the Baumbast family, the R family consists of four people, the French father, the mother who is a us citizen and two children who are both French and us citizens. The situation of the two families differs in the sense that in the Baumbast case the EU-citizen spouse/ parent leaves the Member State to take up an economic activity in a third country. In the $R$ case, the parents are divorced. Following their divorce both parents remain in the host-Member State. As their EU-citizen parent does not leave their host-Member State, the two R children retain their right to remain in that Member State under Article 7(1)(d) of the Citizens Directive as EUlaw does not require family members to cohabit in their host-Member State. Although they live with their third-country national parent after their parents are divorced, their father remains in their host-Member State where he continues to enjoy the status of worker. ${ }^{45}$ The situation is different for the thirdcountry national mother, who following her divorce no longer qualifies as a family member within the meaning of Article 2(2)(a) of the Citizens Directive and, therefore loses her right to remain which she derived from Article 7(2) of the Citizens Directive when married to an EU-citizen. The Court of Justice therefore only has to consider whether the Baumbast children are entitled to remain in their host-Member State after their father's departure. The position of the mother is considered for both families.

Whilst resident in the UK Mr Baumbast has pursued an economic activity in that Member State as a worker and a self-employed person. As children of a (former) worker within the meaning of (now) Article 45 TFEU, the children fall within the scope of Article 10 Regulation (EU) No. 492/2011 and are, therefore, entitled to be 'admitted to [their host-Member] State's general educational, apprenticeship and vocational training courses under the same conditions as the nationals of that State. ${ }^{46}$ Relying on the aim of Regulation (EC) No. 492/2011 - namely, to provide the best possible conditions for the integration of the worker's family in the society of the host Member State thereby ensuring

\footnotetext{
45 Baumbast, nt. 1 cons. 60-62.

46 At the time of the Baumbast case, the relevant provision was Article 12 Regulation (EEC) No. 1612/68 of the Council of 15 October 1968 on freedom of movement for workers within the Community, OJ English Special Edition 1968 (II), p. 475). Although the Court of Justice consistently refers to the repealed Regulation (EEC) No. 1612/68, in the NA case, references in this contribution are made to Regulation (EU) No. 492/2011, the law currently in force.
} 
free movement for workers in compliance with the principles of liberty and dignity ${ }^{47}$ - the Court of Justice reasoned that

to prevent a child of a citizen of the Union from continuing his education in the host-Member State by refusing him permission to remain might dissuade that citizen from exercising the rights to freedom of movement laid down in Article [ $45 \mathrm{TFEU}$ ] and would therefore create an obstacle to the effective exercise of the freedom thus guaranteed by the TFEU. 48

This is only half the story as the children need to be cared for when in education and for this reason need their primary carer in their host-Member State to look after them. The Court of Justice, again invoking the principle of effective rights, extends the right to equal treatment and access to education and the complementary right to remain for the purpose of completing their education which children of a (former) worker enjoy by virtue of Article 10 Regulation (EU) No. 492/2011, to the primary carer. In the words of that Court: 'it is clear that if those parents were refused the right to remain in the host-Member State during the period of their children's education that might deprive those children of a right which is granted to them by the [EU]-legislature. 49 Therefore to ensure that education can be followed under the best possible conditions, children have to be accompanied by the person who is [their] primary carer, and accordingly, that that person is able to reside with him in that Member State during his studies..$^{50}$ Both Mrs Baumbast and Mrs R are the primary carer of their children and in this capacity can continue to reside in the UK with their children.

\subsubsection{Fine-Tuning the Baumbast-Ruling}

The first opportunity offered to the Court of Justice to develop its Baumbastruling was in 2010 when it was asked to adjudicate in the Teixeira and the Ibrahim cases. In the Teixeira case the Court of Justice clarifies that the entry

47 ECJ (Sixth chamber) Case C-308/89 Carmina di Leo v Land Berlin, 13 November 1990, ECLI:EU:C:1990:400, cons. 13 and Baumbast, nt. 1, cons. 51.

48 Baumbast, nt. 1, cons. $5^{2}$.

49 Ibidem, cons. 71. Confirmed in: ECJ (Grand Chamber) Cases C-310/08, London Borough of Harrow v Nimco Hassan Ibrahim and Secretary of State for the Home Department, 23 February 2010, ECLI:Eu:C:2010:80, cons.55; \& C-480/08, Maria Teixeira v London Borough of Lambeth and Secretary of State for the Home Department, 23 February 2010, ECLI:EU:C:2010:83, cons. 37.

5o Baumbast, nt. 1, cons. 73. Confirmed in: Ibrahim, nt. 49, cons. 31. 
into force and expiry of the implementing period for the Citizens Directive do not affect the right to remain that children and their parents derive (indirectly) from (then) Article 12 of Regulation (EEC) No 1612/68. ${ }^{11}$ The other 'follow-up' cases are: Czop \& Punakova, Alarape and Ahmad. ${ }^{52}$

On the substance the Court of Justice first clarifies that the enjoyment of the right to equal access to education in the host-Member States 'depends on the child first being installed in the host-Member State in [his/her] capacity of [a member] of the family of a migrant worker. ${ }^{53}$ It notes that children who have resided with their EU-citizen parent who is, or has been, a worker in their host-Member State since their birth can invoke their right to equal access to education facilities in that Member State as the legal basis for their right to remain after that parent has left that Member State. It qualifies this right to remain as an independent right of residence of the child. ${ }^{54}$ In the words of the Court of Justice

it is enough that the child who is in education in the host Member State became installed there when one of his or her parents was exercising rights of residence there as a migrant worker. The child's right of residence in that State in order to attend educational courses there, in accordance with Article [10 of Regulation No [492/2011], and consequently the right of residence of the parent who is the child's primary carer, cannot therefore be subject to the condition that one of the child's parents worked as a migrant worker in the host Member State on the date on which the child started in education. ${ }^{55}$

In its Teixeira-ruling the Court of Justice also establishes that the primary carer's derived right to remain ends once the children have completed their education. This follows from the purpose to extend the right to remain to the primary carer, namely to ensure 'the best possible conditions' for the children's education. When this moment occurs depends on the facts of each individual

51 Teixeira, nt. 49, cons. 43 .

52 CJ EU (Third Chamber) Case C-147/11, Secretary of State for Work and Pensions v Lucja Czop and Margita Punakova, 6 September 2012, ECLI:EU:C:2012:538; (Second Chamber) Case C-529/11, Olaitan Ajoke Alarape and Olukayode Azeez Tijani v Secretary of State for the Home Department, 8 May 2013, ECLI:EU:C:2013:290; and (Fourth Chamber) Case C-45/12 Office national d'allocations familiales pour travailleurs salariés (ONAFTS) v Radia Hadj Ahmed, 13 June 2013, ECLI:EU:C:2013:390.

53 Teixeira, nt. 49, cons. 45 .

54 Ibidem, cons. $45^{-46 .}$

55 Ibidem, cons. 74. See also: Czop \& Punakova, nt. 52, cons. 26. 
case and is not necessarily linked to the day that child reaches the age of majority. ${ }^{56}$ ' $[\mathrm{I}] \mathrm{f}$ the child continues to need the presence and the care of that parent in order to be able to pursue and complete his or her education', then that parent's right to remain continues to exist. ${ }^{57}$ Facts which are identified by the Court of Justice which determine whether a child needs the care of the primary care are 'the age of the child, whether the child is residing in the family home or whether the child needs financial or emotional support from the parent in order to be able to continue and to complete his education.'58 In the Teixeira case the Court of Justice also adds to our understanding of the right to remain that is derived from Article 10 of Regulation (EU) No 492/2011 that these rights are not 'conditional on self-sufficiency'.59 Applications for benefits cannot therefore be invoked by the Member State to withdraw a right to remain ex Article 10 Regulation (EU) No 492/2011.

Two important limitations follow from the Court of Justice's ruling in the Ahmed case. First of all children born from a previous relationship of the thirdcountry national parent do not qualify as a family member in the descending line of the EU-citizen if the third-county national parent is not a spouse or registered partner of the EU-citizen as they do not qualify as a family member within the meaning of Article 2(2) of the Citizens Directive. This means that the children of the cohabiting third-country national partner born from a previous relationship cannot invoke Article 10 of Regulation (EU) No 492/2011 successfully. ${ }^{60}$ The second limitation is that the primary carer's right to remain that is derived indirectly from Article 10 of Regulation (EU) No. 492/2011 is intrinsically connected to the child having 'entered the educational system in the host-Member State'.61

There are two further limitations to the right to remain ex Article 10 of Regulation (EU) No 492/2011. The first limitation is that this right to remain does not give an entitlement to a permanent right of residence ex Article 16 of the Citizens Directive, as the five years of continued residence condition in this provision means residence in accordance with 'the conditions laid down in Directive 2004/38/EC' ${ }^{\prime 2}$ The second is that as the personal scope of Regulation (EC) No 492/2011 is limited to workers, the children of self-employed persons

\footnotetext{
$56 \quad$ Teixeira, nt. 49 , cons. 78 .

57 Ibidem, cons. 86 and Alarape, nt. 52, cons. 28.

$5^{8}$ Alarape, nt. 52, cons. 30.

59 Teixeira, nt. 49, cons. 86 \& Alarape, nt. 52, cons. 28.

6 o Ahmed, nt. 52, cons. 49-51.

61 Ibidem, cons. 52. With reference to: Czop \& Punakova, nt. 52, cons. 29.

62 Ahmed, nt. 52, cons. 39-40.
} 
and economic inactive EU-citizens cannot claim a right to complete their education and, for this purpose, reside in the host-Member State with their primary carer. ${ }^{63}$ These children could qualify for a right to remain ex Article 12(3) of the Citizens Directive that provides all children and the parent who has actual custody of them, irrespective of their nationality, with a right to remain after the departure or death of the EU-citizen until the children finish their studies, if the children of the EU-citizen were resident in the host-Member State where they were in education, Although the Court of Justice explicitly distinguishes the right to remain derived from Article 10 Regulation (EU) No 492/2011 from that in Article 12(3) of the Citizens Directive in the Teixeira case, it is not clear how these two provisions differ, other than that the former is limited to a worker's children and the latter can be invoked by all children. ${ }^{64}$

\subsection{An Appraisal}

To protect NA as the primary carer of her children, a very extensive interpretation of the children's right to remain is required, as becomes apparent on closer reading of the sections in the $N A$ judgment dedicated to the Baumbast case law. Although the Court of Justice has acknowledged that the right to attend school and reside in the (former) worker's host-Member State includes children born in that Member State, to qualify NA as a primary carer who derives her right to remain from Article 10 Regulation (EU) No 492/2011, in consideration 63 the Court of Justice has to extend its reading of this provision to include children of former workers who have not started to attend school when their EU-citizen parent leaves their host-Member State to ensure that even the eldest child in the $N A$ case benefits from that provision. In its earlier case law, this right was restricted to cases in which a child has actually entered the educational system in the host-Member State. ${ }^{65}$ The wording used in the $N A$ case implies that children can also rely on this provision if they have resided since their birth in the Member State in which [an EU-citizen] was employed, .... The Court of Justice's reading in the NA case, therefore, means that any child born in a Member State where their EU-citizen parent has been employed as a worker in the past, derives a right of residence from Article 10 Regulation (EU) No 492/2011 even if the child was not in education when the EU-citizen parent leaves that Member State or passes away. Considering that the very purpose of granting children the right to attend school in the EU-worker's host-Member

\footnotetext{
63 Czop \& Punakova, nt. 52, cons. 33.

64 Teixeira, nt. 49, cons. 86. See also: Alarape, nt. 52, cons. 28.

65 Czop \& Punakova, nt, 52, cons. 29 and Ahmed, nt. 52, cons. $5^{2}$.
} 
State was to facilitate the EU-worker's integration, ${ }^{66}$ the Court of Justice's reading in the $N A$ case, though it serves the purpose of protecting the mother and children, is far removed from the objective sought by that provision.

The Court of Justice's broad reading of the rights derived from Article 10 Regulation (EU) No 492/2011 raises the question what the legal status of the children is in the intermediate period that commences when their father leaves their host-Member State, which is actually before NA's second child is born, and when they start attending school. Can we assume that in this intermittent period Article 10 of Regulation (EU) No 492/2011 also serves as the legal basis for their right of residence? If not, what is the legal basis for the children's and their primary carer's right to remain? The significance of this 'residence gap' becomes all the more apparent when considered in the light of the Court of Justice's reading of Article 13(2) of the Citizens Directive. According to the Court of Justice's reasoning, NA cannot rely on this provision because she is no longer a family member of a migrant EU-citizen within the meaning of Article 2(2)(a) of the Citizens Directive and therefore loses her right of residence ex Article $7(2)$ of that Directive the moment that her EU-citizen spouse leaves the host-Member State. To benefit from the protection offered by Article 13(2) of the Citizens Directive, so the Court of Justice reasons, would effectively mean that the right to remain that she had lost the moment that her EU-citizen spouse left the host-Member State would be 'revived' the moment that the divorce proceedings were completed. Translated to the Court of Justice's findings regarding the right to remain ex Article 10 Regulation (EU) No 492/2011 this implies that if her children's right to reside only comes into existence when the eldest child starts attending school, she cannot be considered the primary carer of a child in education who needs to reside in the same Member State as the child to ensure the effectiveness of the latter's rights. So what is the legal basis for her residence in the intermediate period?

The Chen case law could solve this residence gap. As the NA children are both nationals of a Member State resident in a host-Member State, they can qualify for a right to remain there if they satisfy the conditions for residence as economic inactive EU-citizens; sufficient financial resources and a health insurance. As the children can qualify as economic inactive EU-citizens if a third party provides for them, the following options are possible. ${ }^{67}$ Either NA herself generates sufficient income for them, for instance using her right to take up

\footnotetext{
66 Baumbast, nt. 1, cons. 45-46.

67 Chen, nt. 4, cons. 30; ECJ case C-408/03, Commission v Belgium, nt. 39, cons. 32, 41-47; Alokpa, nt. 7, cons. 27 and Kuldip Singh, nt. 16, cons. 74 .
} 
employment in the host-Member State in Article 23 of the Citizens Directive, or their father provides for them by paying an allowance for the children and their mother. In the alternative it is also possible that a third party provides for them. As said earlier, the facts of the case are insufficient to determine whether the NA children qualify as economic inactive EU-citizens and NA as the primary carer of economic inactive EU-citizens.

By linking the right to remain in Article 13(2)(c) of Directive 2004/38/EC to having filed for divorce, so it was held in §2.4, the Court of Justice's reading of that provision provides the perpetrator of domestic violence with power over his/her victim. It does not require a very vivid imagination to visualise cases in which the victim of domestic violence is not the sole custodian of children resident in the host-Member State from whom s/he can derive a right to remain in that Member State. This is the case if there are no children in the first place or if the children have accompanied their EU-citizen parent to his/her new place of abode, either in another Member State or outside the EU, either voluntarily or under force. What could the Court of Justice have done, if NA was not the sole custodian of two young children resident in her host-Member State?

In $\S$ 2.4.4 it was suggested that the Court of Justice could have relied on its case law on the declaratory nature of free movement rights to achieve a victim oriented reading of the right to remain in Article 13(2)(c) of the Citizens Directive. Applying the case law on the declaratory nature of free movement rights would allow the Court of Justice to conclude that residence in the hostMember State as a spouse of an EU-citizen who suffers domestic violence whilst resident there would suffice to qualify for protection under that provision. This last section will consider whether the envisaged accession of the EU to the Council of Europe's Convention on Preventing and Combating Violence against Women and Domestic Violence of 12 April 2011 (further: the Convention on Domestic Violence) necessitates a reconsideration of the $N A$ ruling in future cases.

The Convention on Domestic Violence entered into force on 1 August 2014 and now binds fourteen Member States. ${ }^{68}$ In March 2016, the Commission

$68 \mathrm{http://www.coe.int/en/web/conventions/full-list/-/conventions/treaty/210/signatures,}$ last consulted: 1 October 2017 . 
published its proposal on the EU's accession to that Convention. ${ }^{69}$ The EU signed this Convention on 13 June 2017..$^{70}$ Article 59(1) of the Convention on Domestic Violence obliges the Contracting Parties to

take the necessary legislative or other measures to ensure that victims whose residence status depends on that of the spouse or partner as recognised by internal law, in the event of the dissolution of the marriage or the relationship, are granted in the event of particularly difficult circumstances, upon application, an autonomous residence permit irrespective of the duration of the marriage or the relationship. The conditions relating to the granting and duration of the autonomous residence permit are established by internal law.

Article 59(2) of the Convention on Domestic Violence requires Contracting Parties to

take the necessary legislative or other measures to ensure that victims may obtain the suspension of expulsion proceedings initiated in relation to a residence status dependent on that of the spouse or partner as recognised by internal law to enable them to apply for an autonomous residence permit.

Although Article 78(2) of this Convention provides Contracting Parties with an option to 'make a reservation not to apply or to apply only in specific cases or conditions the provisions laid down in ... Article 59', from the available documents it does not appear that the EU envisages doing so. Even if no reservation is made, Article 59 of the Convention does provide its Contracting Parties with scope to determine in their internal law that the right to remain for victims of domestic violence after dissolution of their marriage is not unconditional. This could cover the condition that divorce has to be applied for prior to the departure of the EU-citizen from the host-Member State. However, so it is reasoned, this would run counter to the very purpose of that Convention, as spelled out in Article 1(1)(a), namely to 'protect women against all forms of violence, and

69 Proposal for a Council Decision on the signing, on behalf of the European Union, of the Council of Europe Convention on preventing and combating violence against women and domestic violence, 4 March 2016, сом(2016) 111, final.

70 The dates of ratification and entry inforce for the EU were not known, on completion of this contribution. See: https://www.coe.int/en/web/conventions/full-list/-/conventions/ treaty/country/1?p_auth=N81D2NHR. 
prevent, prosecute and eliminate violence against women and domestic violence', as this condition, as already stated, provides the perpetrator of domestic violence with power over the victim and therefore does not contribute towards the protection and elimination of violence against women.

Not subjecting the right to remain as a victim of domestic violence to the condition that divorce proceedings have been lodged prior to the departure of the EU-citizen spouse from the host-Member State also appears to be in line with the EU's policy goal underlying accession to this Convention, identified by the Commission, namely to protect victims of domestic violence. After acknowledging that the Convention's approach is 'fully in line with the Union's multifaceted approach to the phenomenon of gender-based violence and the thrust of measures in place through internal and external EU policies,' the Commission sets out that the EU's accession to the Convention on Domestic Violence

would send a strong political message about the EU's commitment to combating violence against women, create coherence between its internal and external action, as well as complementarity between national and EU levels, and reinforce its credibility and accountability towards its international partners. It would also consolidate the Eu's action targeting violence against women by achieving a more coordinated approach internally and giving it a more effective role in international fora. ${ }^{71}$

If there is a political commitment to ensure the protection of victims of domestic violence, then the legal challenge is to provide them with a right that aims to protect them which they can enforce, if necessary in court.

This contribution has set out how the Court of Justice could have just as easily reached a victim oriented reading of the right to remain in Article 13(2) of the Citizens Directive relying on the wording and drafting history of this provision. In addition, the declaratory nature of free movement rights and in the future the EU's accession to the Convention on Preventing and Combating Violence against Women and Domestic Violence can be used by that Court in support of a victim oriented reading of this provision; a reading that allows survivors of domestic violence to remain in their host-Member State, irrespective when divorce proceedings were lodged and not making them dependent on the presence of children for whom they are the primary carer in their hostMember State.

$71 \quad \operatorname{com}(2016) 111$, final, p. 7. 